\title{
Crystal structure of the $\mathrm{Sr}_{6} \mathrm{Nb}_{4} \mathrm{ZrO}_{18}$ slab perovskite-like compound
}

Yuri Titov $^{\mathrm{a}^{*}}$, Nadegda Belyavina ${ }^{\mathrm{b}}$, Mikola Slobodyanik $^{\mathrm{a}}$, Vitaly Polubinskii ${ }^{\mathrm{a}}$, Olesya Nakonechna ${ }^{\mathrm{b}}$

a Department of Chemistry, Taras Shevchenko National University of Kyiv, Volodymyrska Street, 64/13, Kyiv 01601, Ukraine

${ }^{\mathrm{b}}$ Department of Physics, Taras Shevchenko National University of Kyiv, Acad. Glushkova avenue, 4-b, Kyiv 03022, Ukraine

contactinge-mail tit@univ.kiev.ua

Keywords: oxides, heat treatment, Rietveld analysis, crystal structure, dielectric properties.

\begin{abstract}
The $\mathrm{Sr}_{6} \mathrm{Nb}_{4} \mathrm{ZrO}_{18}$ niobatozirconate has been synthesized from the $\mathrm{Sr}_{5} \mathrm{Nb}_{4} \mathrm{O}_{15}$ four-layer perovskite and the $\mathrm{SrZrO}_{3}$ perovskite at $T=1670 \mathrm{~K}$ by ceramic technique. Crystal structure of the $\mathrm{Sr}_{6} \mathrm{Nb}_{4} \mathrm{ZrO}_{18}$ compound has been studied by the X-ray powder diffraction method. It was shown that crystal structure of the $\mathrm{Sr}_{6} \mathrm{Nb}_{4} \mathrm{ZrO}_{18}(a=0.5687(1) \mathrm{nm}, c=4.146(1) \mathrm{nm}, R-3 m$ space group$)$ belongs to the $\mathrm{Ba}_{6} \mathrm{Nb}_{4} \mathrm{TiO}_{18}$-type with five-layer perovskite-like structure. The crystal structure features of the $\mathrm{Sr}_{6} \mathrm{Nb}_{4} B^{\mathrm{IV}} \mathrm{O}_{18}$ compounds $\left(B^{\mathrm{IV}}=\mathrm{Ti}, \mathrm{Sn}, \mathrm{Zr}\right)$ has been analyzed. The correlation between composition and crystal structure features for all $\mathrm{Sr}_{6} \mathrm{Nb}_{4} B^{\mathrm{IV}} \mathrm{O}_{18}$ compounds, which leads to destruction slab perovskite-like structure has been revealed.
\end{abstract}

\section{Introduction}

Recent studies in the field filed of microwave technology have an increased focus on the compounds of the $A_{n} B_{n-1} \mathrm{O}_{3 n}$ and $\mathrm{A}_{\mathrm{n}} \mathrm{B}_{\mathrm{n}} \mathrm{O}_{3 \mathrm{n}+1}$ families $(A=\mathrm{Ba}, \mathrm{Sr}, \mathrm{Ca}, \mathrm{Ln}, \mathrm{Nd} ; B=$ Ti, Nb, Ta, Sn, Zr, W, Re, Al, Ga, Cr, Fe, Mg; $n=3-7)$ with a slab perovskite-like structure (SPS) due to their excellent dielectric properties (such as high quality factors and high dielectric constants) [1-12]. In particular, as it is shown in [6-11], the dielectric constant $\left(\varepsilon_{r}\right)$ range is from 26 to 48 while the quality factor $(Q \times f)$ is decreasing from 5600 to $51000 \mathrm{Ghz}$ for the $A_{6} B_{5} \mathrm{O}_{18}$ five-layer ceramics $(A=\mathrm{Ba}, \mathrm{Sr}, \mathrm{La} ; B=$
$\mathrm{Nb}, \mathrm{Ta}, \mathrm{Ti}, \mathrm{Zr}, \mathrm{Mg}, \mathrm{Zn} ; n=5)$. Besides, the temperature coefficient of the resonant frequency changes from -39 to $+183 \mathrm{ppm} /{ }^{\circ} \mathrm{C}$ with the composition of these compounds. Moreover, a study of the dielectric characteristics of the $\mathrm{Sr}_{6} \mathrm{Nb}_{4} \mathrm{~B}^{\mathrm{IV}} \mathrm{O}_{18}\left(B^{\mathrm{IV}}=\mathrm{Ti}\right.$, $\mathrm{Zr})$ compounds $\left(A_{\mathrm{n}} B_{\mathrm{n}-1} \mathrm{O}_{3 \mathrm{n}}\right.$ five-layer family representatives) has shown that substitution of titanium for zirconium leads to a significant improvement of microwave properties [11]. At high values $(\sim 40)$ of the dielectric constant for both compounds, the quality factor $(Q \times f)$ for the $\mathrm{Sr}_{6} \mathrm{Nb}_{4} \mathrm{ZrO}_{18}$ is more than three times greater than the corresponding value for the 
$\mathrm{Sr}_{6} \mathrm{Nb}_{4} \mathrm{TiO}_{18} \quad(21000 \mathrm{Ghz}$ and $6700 \mathrm{Ghz}$ respectively). At the same time the temperature coefficient of the resonance frequency $\left(\tau_{\mathrm{f}}\right)$ for $\mathrm{Sr}_{6} \mathrm{Nb}_{4} \mathrm{ZrO}_{18}\left(-8 \mathrm{ppm} /{ }^{\circ} \mathrm{C}\right)$ is much closer to zero than that for $\mathrm{Sr}_{6} \mathrm{Nb}_{4} \mathrm{TiO}_{18}\left(26 \mathrm{ppm} /{ }^{\circ} \mathrm{C}\right)$ [11]. Such a high value of the quality factor provides a narrow bandwidth, which ensures the selection of the frequency range desired while $\tau_{\mathrm{f}}$ value close to zero is important to minimize the temperature fluctuations of resonant frequency [10]. The structural feature of the $A_{\mathrm{n}} B_{\mathrm{n}-1} \mathrm{O}_{3 \mathrm{n}}$ slab perovskite-like compounds is another important factor along with the chemical composition that has an effect on their properties [10]. However, it's worth to mention that among a number of strontium-containing five-layer compounds of the $\mathrm{Sr}_{6} \mathrm{Nb}_{4} B^{\mathrm{IV}} \mathrm{O}_{18}$-type $\left(B^{\mathrm{IV}}=\mathrm{Ti}, \mathrm{Sn}, \mathrm{Zr}\right)$, the crystal structures have been determined only for $\mathrm{Sr}_{6} \mathrm{Nb}_{4} \mathrm{TiO}_{18}$ and $\mathrm{Sr}_{6} \mathrm{Nb}_{4} \mathrm{SnO}_{18}[13,14]$. This complicates the conception of nature of the electrophysical properties of the $A_{6} B_{5} \mathrm{O}_{18}$ family.

The aim of present study was to determine the crystal structure of the $\mathrm{Sr}_{6} \mathrm{Nb}_{4} \mathrm{ZrO}_{18}$ perovskite-like compound and to find out the composition/crystal structure correlation for the whole family of the $\mathrm{Sr}_{6} \mathrm{Nb}_{4} B^{\mathrm{IV}} \mathrm{O}_{18}$ slab perovskite-like compounds $\left(B^{\mathrm{IV}}=\mathrm{Ti}, \mathrm{Sn}, \mathrm{Zr}\right)$.

\section{Results and discussion}

The X-ray powder diffraction study reveals that the diffraction pattern of the
$\mathrm{Sr}_{6} \mathrm{Nb}_{4} \mathrm{ZrO}_{18}$ compound synthesized is similar to those of the $A_{\mathrm{n}} B_{\mathrm{n}-1} \mathrm{O}_{3 \mathrm{n}}$ ones $(n=6)$ studied earlier, namely: $\mathrm{Sr}_{6} \mathrm{Nb}_{4} \mathrm{TiO}_{18}$ ( $R 3 m$ space group) [13], $\mathrm{Ba}_{2} \mathrm{La}_{4} \mathrm{Ti}_{5} \mathrm{O}_{18}(R-3)$ [17], $\mathrm{Sr}_{6} \mathrm{Nb}_{4} \mathrm{SnO}_{18}$ and $\mathrm{Ba}_{6} \mathrm{Nb}_{4} \mathrm{TiO}_{18}(R-3 m)[14,18]$. So, taking into account the data available for $A_{\mathrm{n}} B_{\mathrm{n}-1} \mathrm{O}_{3 \mathrm{n}}$ compounds the pattern of the $\mathrm{Sr}_{6} \mathrm{Nb}_{4} \mathrm{ZrO}_{18}$ was indexing well within the rhombohedral unit cell (Figure 1).

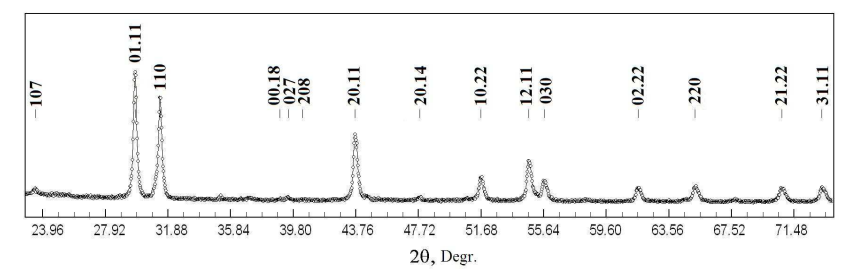

Figure 1. X-Ray pattern of the $\mathrm{Sr}_{6} \mathrm{Nb}_{4} \mathrm{ZrO}_{18}$ compound, $\mathrm{Cu} K_{\alpha}$ radiation.

The test for the generation of the second optical harmonic of the laser radiation signal by the $\mathrm{Sr}_{6} \mathrm{Nb}_{4} \mathrm{ZrO}_{18}$ polycrystalline sample has shown that the relative intensity of the $I_{2 \omega}$ signal for compound mentioned as well as the centrosymmetical $\mathrm{Ba}_{2} \mathrm{La}_{4} \mathrm{Ti}_{5} \mathrm{O}_{18}$ is less than 0.01 $I_{2 \omega}$ of the noncentrosymmetrical $\mathrm{Sr}_{6} \mathrm{Nb}_{4} \mathrm{TiO}_{18}$. Such negligible value of the $I_{2 \omega}$ signal clearly certifies that the slab perovskite structure of the $\mathrm{Sr}_{6} \mathrm{Nb}_{4} \mathrm{ZrO}_{18}$ compound belongs to the centrosymmetrical space group.

Based on the result of diffraction pattern indexing and the nonlinear optical data we have refined two trial centrosymmetrical models for the $\mathrm{Sr}_{6} \mathrm{Nb}_{4} \mathrm{ZrO}_{18}$ structure $(R-3 m$ and $R-3$ space groups) using atom coordinates of the $\mathrm{Ba}_{6} \mathrm{Nb}_{4} \mathrm{TiO}_{18}$ [18] and $\mathrm{Ba}_{2} \mathrm{La}_{4} \mathrm{Ti}_{5} \mathrm{O}_{18}$ [17] compounds as initial ones. Unfortunately, it is impossible to distinguish the atomic scattering 
factors for $\mathrm{Zr}$ and $\mathrm{Nb}$ atoms so we cannot define correctly their arrangement in the crystal structure using the X-ray powder diffraction methods. That is why, the refinement of the $\mathrm{Sr}_{6} \mathrm{Nb}_{4} \mathrm{ZrO}_{18}$ structure has been made by taking into account a statistical distribution of $\mathrm{Zr} / \mathrm{Nb}$ atoms over positions in the $\mathrm{Sr}_{6} \mathrm{Nb}_{4} \mathrm{ZrO}_{18}$ structure which are filled with these atoms (block's center $(3 b)$, block's boundary $(6 c)$ and intermediate position $(6 c)$ ) (Table 1).

Table 1. Crystal data for $\mathrm{Sr}_{6} \mathrm{Nb}_{4} \mathrm{ZrO}_{18}$ compound.

\begin{tabular}{c|c|c|c|c}
\hline Atom & Sit & $x$ & $y$ & $z$ \\
\hline $\mathrm{Sr}(1)$ & $6 c$ & 0 & 0 & $0.1379(2)$ \\
\hline $\mathrm{Sr}(2)$ & $6 c$ & 0 & 0 & $0.3177(2)$ \\
\hline $\mathrm{Sr}(3)$ & $6 c$ & 0 & 0 & $0.4116(3)$ \\
\hline$(0.8 \mathrm{Nb}+0.2 \mathrm{Zr})(1)$ & $6 c$ & 0 & 0 & $0.0480(2)$ \\
\hline$(0.8 \mathrm{Nb}+0.2 \mathrm{Zr})(2)$ & $6 c$ & 0 & 0 & $0.2250(2)$ \\
\hline$(0.8 \mathrm{Nb}+0.2 \mathrm{Zr})(3)$ & $3 b$ & 0 & 0 & 0.5 \\
\hline $\mathrm{O}(1)$ & $18 h$ & $0.519(3)$ & $0.481(3)$ & $0.140(2)$ \\
\hline $\mathrm{O}(2)$ & $18 h$ & $0.507(2)$ & $0.493(3)$ & $0.307(2)$ \\
\hline $\mathrm{O}(3)$ & $18 h$ & $0.493(3)$ & $0.507(3)$ & $0.419(2)$ \\
\hline Space group & \multicolumn{5}{|c}{$R-3 m$} \\
\hline Lattice parameters, $a, c, \mathrm{~nm}$ & $a=0.5687(1) ; c=4.146(1)$ \\
\hline Independent reflections & \multicolumn{5}{|c}{0.055} \\
\hline Total isotropic factor $B, \mathrm{~nm}{ }^{2}$ & \multicolumn{5}{|c}{133} \\
\hline Reliability factor $R_{I}$ & \multicolumn{5}{c}{$\mathrm{e}$} & \\
\hline
\end{tabular}

As a results of structure parameter refinement two identical values of the reliability factor $\left(R_{I}=0.055\right)$ have been obtained for both centrosymmetric models $(R-3 m$ and $R-3$ space groups). In such cases, the preference is usually given to the high ordered form. Therefore, the $R-3 m$ space group has been selected for the $\mathrm{Sr}_{6} \mathrm{Nb}_{4} \mathrm{ZrO}_{18}$ compound with SPS.

The final results of the crystal structure refinement for the $\mathrm{Sr}_{6} \mathrm{Nb}_{4} \mathrm{ZrO}_{18}$ compound (including details on atomic distribution) are listed in Table 1.The selected interatomic distances calculated using data Table $\mathbf{1}$ are presented in Table 2. It should be noted that the composition of the $\mathrm{Sr}_{6} \mathrm{Nb}_{4} \mathrm{ZrO}_{18}$ obtained form the structural refinement calculation corresponds to an experimentally given one within the measurement error.

Table 2. Selected interatomic distances $(d)$ and degree of distortion $(\Delta)$ of $\mathrm{MeO}_{\mathrm{n}}$ polyhedra in the crystal structure of $\mathrm{Sr}_{6} \mathrm{Nb}_{4} \mathrm{ZrO}_{18}$.

\begin{tabular}{c|c|c|c}
\hline Atom - atom and $\Delta^{1)}$ & $d, \mathrm{~nm}$ & Atom - atom and $\Delta$ & $d, \mathrm{~nm}$ \\
\hline $\mathrm{Sr}(1)-3 \mathrm{O}(1)$ & $0.272(2)$ & $\mathrm{Sr}(3)-\mathrm{O}_{\text {aver. }}$ & 0.2905 \\
\hline$-6 \mathrm{O}(1)$ & $0.285(3)$ & $\Delta \mathrm{Sr}(3) \mathrm{O}_{12}$ & $26 \cdot 10^{-4}$ \\
\hline$-3 \mathrm{O}(3)$ & $0.276(2)$ & $(\mathrm{Nb}, \mathrm{Zr})(1)-3 \mathrm{O}(2)$ & $0.181(1)$ \\
\hline $\mathrm{Sr}(1)-\mathrm{O}_{\text {aver. }}$ & 0.2795 & $-3 \mathrm{O}(3)$ & $0.232(2)$ \\
\hline$\Delta \mathrm{Sr}(1) \mathrm{O}_{12}$ & $4 \cdot 10^{-4}$ & $(\mathrm{Nb}, \mathrm{Zr})(1)-\mathrm{O}_{\text {aver. }}$ & 0.2065 \\
\hline $\mathrm{Sr}(2)-3 \mathrm{O}(2)^{2)}$ & $0.244(2)$ & $\Delta(\mathrm{Nb}, \mathrm{Zr})(1) \mathrm{O}_{6}$ & $152 \cdot 10^{-4}$ \\
\hline$-6 \mathrm{O}(2)$ & $0.288(2)$ & $(\mathrm{Nb}, \mathrm{Zr})(2)-3 \mathrm{O}(3)$ & $0.183(1)$ \\
\hline$-3 \mathrm{O}(3)$ & $0.330(2)$ & $-3 \mathrm{O}(1)$ & $0.196(2)$ \\
\hline $\mathrm{Sr}(2)-\mathrm{O}_{\text {aver. }}$ & 0.2875 & $(\mathrm{Nb}, \mathrm{Zr})(2)-\mathrm{O}_{\text {aver. }}$ & 0.1895 \\
\hline$\Delta \mathrm{Sr}(2) \mathrm{O}_{12}$ & $112 \cdot 10^{-4}$ & $\Delta(\mathrm{Nb}, \mathrm{Zr})(2) \mathrm{O}_{6}$ & $12 \cdot 10^{-4}$ \\
\hline $\mathrm{Sr}(3)-3 \mathrm{O}(2)$ & $0.275(2)$ & $(\mathrm{Nb}, \mathrm{Zr})(3)-6 \mathrm{O}(1)$ & $0.214(2)$ \\
\hline$-6 \mathrm{O}(3)$ & $0.286(2)$ & $(\mathrm{Nb}, \mathrm{Zr})(3)-\mathrm{O}_{\text {aver. }}$ & 0.214 \\
\hline$-3 \mathrm{O}(1)$ & $0.315(3)$ & $\Delta(\mathrm{Nb}, \mathrm{Zr})(3) \mathrm{O}_{6}$ & 0 \\
\hline $\mathrm{T}$ &
\end{tabular}

1) The degrees of distortion of the $\mathrm{MeO}_{n}$ polyhedra were calculated as $\Delta=1 / n \sum\left[\left(R_{i}-\bar{R}\right) / \bar{R}\right]^{2}$ (where $R_{i}$ is the Me - O distance, $\bar{R}$ is the $M e-\mathrm{O}$ average distance, $n$ is the coordination number for $M e$ ) [19].

2) Interblock distance $(\mathrm{O}(2)$ atom located in the neighbor perovskite-like block).

Taking into account the data obtained on the atomic arrangement and interatomic distances (Tables 1, 2) it was shown that the two-dimensional perovskite-like blocks, consisting of five vertex-sharing $(\mathrm{Nb}, \mathrm{Zr}) \mathrm{O}_{6}$ octahedra are the basic structural units of the $\mathrm{Sr}_{6} \mathrm{Nb}_{4} \mathrm{ZrO}_{18}$ crystal structure (Figure 2). There is no a direct connection between those perovskite-like blocks; they are connected just through the $\operatorname{Sr}(2)-\mathrm{O}(2)$ bond. 


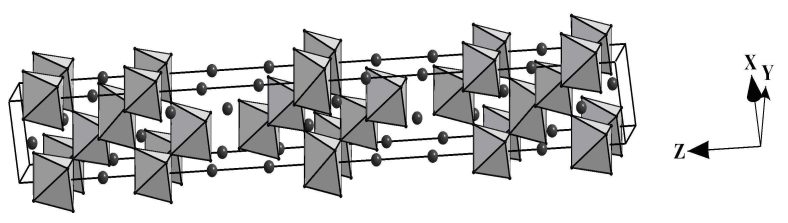

Figure 2. Crystal structure of the $\mathrm{Sr}_{6} \mathrm{Nb}_{4} \mathrm{ZrO}_{18}$ compound as an arrangement of the $(\mathrm{Nb}, \mathrm{Zr}) \mathrm{O}_{6}$ octahedra and $\mathrm{Sr}$ atoms (black circles).

The $\mathrm{SrO}_{12}$ cuboctahedron is a coordination polyhedron for all strontium atoms in the $\mathrm{Sr}_{6} \mathrm{Nb}_{4} \mathrm{ZrO}_{18}$ compound. The $\mathrm{Sr}(1) \mathrm{O}_{12}$ cuboctahedra placed in the center of the perovskite-like block have the lowest distortion ratio among those polyhedra. On the contrary, the $\operatorname{Sr}(2) \mathrm{O}_{12}$ cuboctahedra located on the perovskite-like block boundary possess the highest distortion ratio (Table 2). Nine oxygen atoms of the external $\operatorname{Sr}(2) \mathrm{O}_{12}$ polyhedron, namely, six $\mathrm{O}(2)$ and three $\mathrm{O}(3)$ belong to the same block of $\operatorname{Sr}(2)$ atoms, the rest of oxygen atoms belongs to the adjacent block (Figure 3).

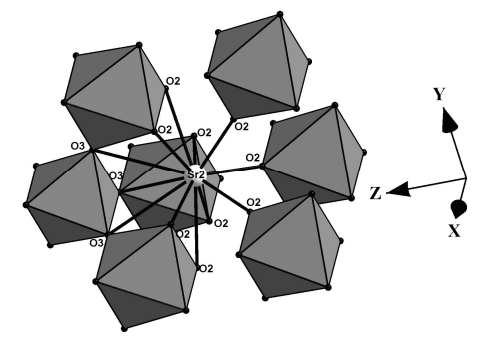

Figure 3. Interblock boundary construction for the $\mathrm{Sr}_{6} \mathrm{Nb}_{4} \mathrm{ZrO}_{18}$.

As mentioned above, the approach of the $\mathrm{Zr} / \mathrm{Nb}$ atoms' statistical distribution has been used for structural calculations of the positions in the center $(3 b)$ and boundary $(6 c)$ of the perovskite-like blocks as well as for $(6 c)$ intermediate position (Table 1). So, taking into account the impossibility of determining the arrangement of the $\mathrm{Zr} / \mathrm{Nb}$ atoms by X-ray diffraction, study of the probable distribution of these atoms within perovskite-like blocks of the $\mathrm{Sr}_{6} \mathrm{Nb}_{4} \mathrm{ZrO}_{18}$ compound was carried out by the analysis of the effective valence bonds' sums for the $\mathrm{Zr} / \mathrm{Nb}$ atoms in the $\left(\mathrm{Nb}_{1-x} \mathrm{Zr}_{x}\right) \mathrm{O}_{6}$ polyhedra. The value of the $\left(\mathrm{Nb}_{1-x} \mathrm{Zr}_{x}\right)-\mathrm{O}$ effective valence bond $(s)$ has been calculated as [20]:

$$
s=\exp \left(\frac{B_{0 E f}-R}{B}\right)
$$

where $R_{0 e f}$ is a reference value of the monovalent bond length; $R$ is a experimental value of the $\left(\mathrm{Nb}_{1-x} \mathrm{Zr}_{x}\right)-\mathrm{O}$ bond length; $B$ is a reference value of the dispersion bond length, which is equal to $0.037 \mathrm{~nm}$.

In turn, the $R_{0 e f}$ value has been calculated as:

$$
R_{0 \text { of }}=(1-x) R_{0}(N b)+x R_{0}(Z r)(2),
$$

where $R_{0}(\mathrm{Nb})$ and $R_{0}(\mathrm{Zr})$ are the reference values of the monovalent bond length for $\mathrm{Nb}$ and $\mathrm{Zr}$ atoms, respectively; $x$ is the occupation density degree for zirconium atom.

The total value of the effective valence bonds ( $\left.S_{\text {total }}\right)$ was found as a sum of all $\left(\mathrm{Nb}_{1-x} \mathrm{Zr}_{\mathrm{x}}\right)-\mathrm{O}$ effective valence bonds, namely: $s_{\text {total }}=\Sigma s \cdot n$, where, $n$ is the number of all bonds of this type.

Analysis of the $S_{\text {total }}$ calculated values for $\left(\mathrm{Nb}_{1-x} \mathrm{Zr}_{x}\right)(1)$ bonds (6c position located on the block boundary) and for $\left(\mathrm{Nb}_{1-x} \mathrm{Zr}_{x}\right)(3)$ bonds $(3 b$ position located in the center of the block) has shown that the best agreement of their values with the average valence of metals in the $\left(\mathrm{Nb}_{1-x} \mathrm{Zr}_{x}\right) \mathrm{O}_{6}$ octahedra takes place at a preferable arrangement of the niobium atoms on 
the block's boundary and zirconium atoms in the center of the block (Figure 4).

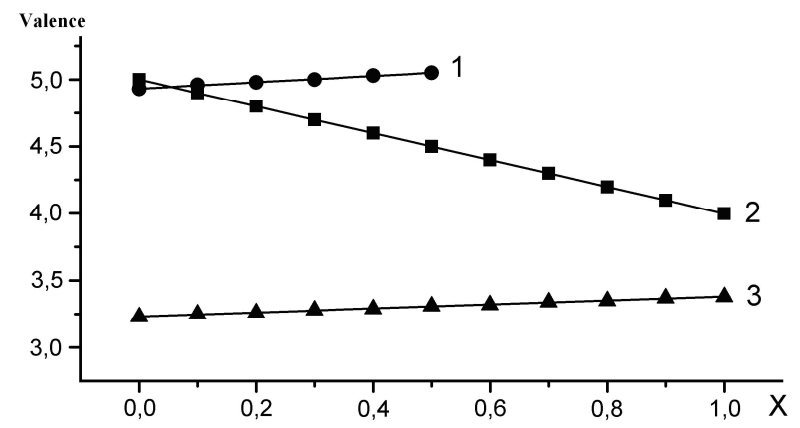

Figure 4. The concentration dependences of the average valences of the metal atoms in the $\left(\mathrm{Nb}_{1-\mathrm{x}} \mathrm{Zr}_{\mathrm{x}}\right) \mathrm{O}_{6}$ octahedra (curve 2) and the total calculated values of the effective valences' bonds $\left(S_{\text {total }}\right)$ of metal atoms in the $\left(\mathrm{Nb}_{1-\mathrm{x}} \mathrm{Zr}_{\mathrm{x}}\right) \mathrm{O}_{6}$ octahedra located on the block boundary (position $(6 c)$, curve 1) and in the center of the block (position $(3 b)$, curve 3 ). $R_{0}=0.1911 \mathrm{~nm}$ for $\mathrm{Nb}-\mathrm{O}$ bond, $R_{0}=0.1928$ $\mathrm{nm}$ for $\mathrm{Zr}-\mathrm{O}$ bond, $B=0.037 \mathrm{~nm}$ [20].

So, results obtained confirm the previous data [14] on primary ordering of the $B^{4+}$ and $\mathrm{Nb}^{5+}$ cations in the octahedron positions of the five-layer blocks of the $A^{\mathrm{II}}{ }_{6} \mathrm{Nb}_{4} B^{\mathrm{IV}} \mathrm{O}_{18}$ compounds $\left(A^{\mathrm{II}}=\mathrm{Sr}, \mathrm{Ba}, B^{\mathrm{IV}}=\mathrm{Ti}, \mathrm{Sn}\right)$. In our opinion, the charge balance condition on the block boundaries and the features of the electronic structure of the $A^{I I}{ }_{6} \mathrm{Nb}_{4} B^{I V} \mathrm{O}_{18}$ family compounds are the most probable reasons for the preferred localization of the $B^{4+}$ cations in the center of the blocks as well as of the $\mathrm{Nb}^{5+}$ cations on the boundary of blocks.

Data obtained here on the crystal structure of the $\mathrm{Sr}_{6} \mathrm{Nb}_{4} \mathrm{ZrO}_{18}$ compound along with our previous results on the $\mathrm{Sr}_{6} \mathrm{Nb}_{4} \mathrm{SnO}_{18}$ crystal structure [14] and data on the crystal structure of the $\mathrm{Sr}_{6} \mathrm{Nb}_{4} \mathrm{TiO}_{18}$ [13], made it possible to identify the influence of the size of $B$ atoms on the crystal-chemical characteristics of compounds of the $\mathrm{Sr}_{6} \mathrm{Nb}_{4} B \mathrm{BO}_{18}(\mathrm{~B}=\mathrm{Ti}, \mathrm{Sn}, \mathrm{Zr})$ family. So, as it is seen from Figure 5, the increasing of the ionic radius of $B$ atoms is accompanied by the decreasing of the distances between adjacent perovskite-like blocks.

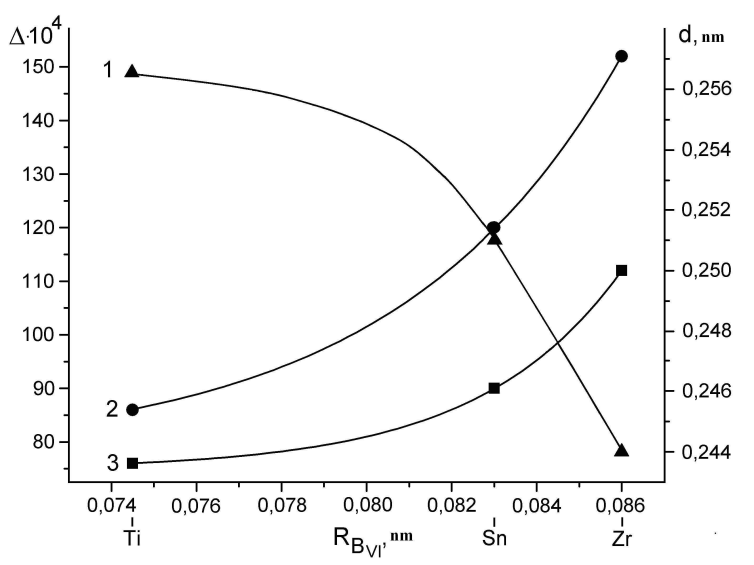

Figure 5. The dependences of the interblock $\mathrm{Sr}-\mathrm{O}$ distances $(d)$ (curve1), degrees of distortion $(\Delta)$ of the $(\mathrm{Nb}, \mathrm{B}) \mathrm{O}_{6}$ (curve 2) and $\mathrm{SrO}_{12}$ (curve3) external block polyhedra versus crystalline ionic radius [19] of $B$ atom in the $\mathrm{Sr}_{6} \mathrm{Nb}_{4} \mathrm{BO}_{18}(B=\mathrm{Ti}, \mathrm{Sn}, \mathrm{Zr})$ compounds with SPS.

This certifies that $\mathrm{Sr}_{6} \mathrm{Nb}_{4} B \mathrm{O}_{18}$ SPS is approaching to the highly stable perovskite structure. Meanwhile, increasing in $B$ atom ionic radius is attended with significant increasing in the deformation degree of the $(\mathrm{Nb}, B) \mathrm{O}_{6}$ and $\mathrm{SrO}_{12}$ external slab polyhedra, which leads to increase of tension in between the blocks in the SPS of $\mathrm{Sr}_{6} \mathrm{Nb}_{4} B \mathrm{O}_{18}$ compounds. So, the structural features of the $\mathrm{Sr}_{6} \mathrm{Nb}_{4} B \mathrm{O}_{18}$ compounds reveal the decrease of stability of these compounds with increasing of $B$ atom's size. On our opinion, this fact demonstrates the impossibility of existence of the $\mathrm{Sr}_{6} \mathrm{Nb}_{4} B \mathrm{O}_{18}$ compounds with the atoms of $B$-type larger than a zirconium atom in size. 


\section{Conclusions}

The crystal structure of the $\mathrm{Sr}_{6} \mathrm{Nb}_{4} \mathrm{ZrO}_{18}$ perovskite-like compound, which is a representative of the $A_{n} B_{n-1} \mathrm{O}_{3 n}$ five-layer perovskite-like family has been studied for the first time. The X-ray powder diffraction data have revealed that crystal structure of this compound belongs to the $\mathrm{Ba}_{6} \mathrm{Nb}_{4} \mathrm{TiO}_{18}$-type.

We have considered the correlation between compositions and crystal structure features for all $\mathrm{Sr}_{6} \mathrm{Nb}_{4} B^{\mathrm{IV}} \mathrm{O}_{18}\left(B^{\mathrm{IV}}=\mathrm{Ti}, \mathrm{Sn}, \mathrm{Zr}\right)$ five-layer compounds, which leads to destruction SPS.

Moreover, the correlation between features of the slab perovskite-like structures both for the $\mathrm{Sr}_{6} \mathrm{Nb}_{4} \mathrm{ZrO}_{18}$ compound studied here and the $\mathrm{Sr}_{6} \mathrm{Nb}_{4} \mathrm{TiO}_{18}$ previously studied and dielectric properties of the $\mathrm{Sr}_{6} \mathrm{Nb}_{4} B^{\mathrm{IV}} \mathrm{O}_{18}$ $\left(B^{\mathrm{IV}}=\mathrm{Ti}, \mathrm{Zr}\right)$ compounds has been established. In particular, taking into account the similarity of the four and five valence cations' distribution in the SPS of $\mathrm{Sr}_{6} \mathrm{Nb}_{4} B^{\mathrm{IV}} \mathrm{O}_{18}\left(B^{\mathrm{IV}}=\mathrm{Ti}, \mathrm{Zr}\right)$ compounds, we can assume that a higher deformation degree both of the $\operatorname{Sr}(2) \mathrm{O}_{12}$ external block polyhedra and the $(\mathrm{Nb}, \mathrm{Zr}) \mathrm{O}_{6}$ external block octahedra is the main structural factor affecting in more than three times increasing of quality factor for the $\mathrm{Sr}_{6} \mathrm{Nb}_{4} \mathrm{ZrO}_{18}$ compound. Besides, the temperature coefficient of resonant frequency for the $\mathrm{Sr}_{6} \mathrm{Nb}_{4} \mathrm{ZrO}_{18}$ is approaching to zero.

\section{Experimental part}

The polycrystalline sample of the $\mathrm{Sr}_{6} \mathrm{Nb}_{4} \mathrm{ZrO}_{18}$ compound has been synthesized by the $\mathrm{Sr}_{5} \mathrm{Nb}_{4} \mathrm{O}_{15}+\mathrm{SrZrO}_{3}$ reaction using the solid state method. An equimolar mixture of the $\mathrm{Sr}_{5} \mathrm{Nb}_{4} \mathrm{O}_{15}$ pre-synthesized perovskite-slab compound and the $\mathrm{SrZrO}_{3}$ perovskite has been pressed $\left(P=3 \cdot 10^{8} \mathrm{~Pa}\right)$ into a tablet and exposed to the progressive heat treatment $(1570 \mathrm{~K}(3+$ 3) h, 1670 K 2 h). Each sample treated has been grinded and repressed after every stage of heat treatment.

The X-ray powder diffraction data were collected with a DRON-3 automatic diffractometer $(\mathrm{Cu} K \alpha$ radiation). The diffraction patterns were obtained in a discrete mode under the following scanning parameters: observation range $2 \theta=(10-90)^{\circ}$, step scan of $0.03^{\circ}$, counting time per step at $5 \mathrm{~s}$. The peak positions and integral intensities of the observed reflections were determined using full profile analysis. After removal of the $\mathrm{CuK \alpha}_{2}$ components the diffraction profiles were fitted with the Lorentz function. The peak positions and integral intensities were calculated with the accuracy not less than $\pm(0.001-0.005)^{\circ}$ and $\pm(5-10) \%$, respectively.

The original software package elaborated for the automated DRON equipments and including both full complex of the Rietveld refinement procedure and special banks (for the $\mathrm{X}$-ray diffraction data and crystal structures of intermetallic and inorganic compounds) was 
used [15] in order to determine phase compositions of the samples and to carry out indexing of the single-phase patterns by the Ito method. Tests of the suggested structural models and structural parameter refinements (including refinement of the atom contents) were carried out from powder diffraction data using the software complex of Ref. [15].

For the $\mathrm{Sr}_{6} \mathrm{Nb}_{4} \mathrm{ZrO}_{18}$ polycrystalline sample prepared, the test to determine its centro / noncentro symmetry was carried out by the procedure described in [16]: Nd: YAG laser $\left(\lambda_{\omega}=1.064 \mu \mathrm{m}\right.$ and $\left.\lambda_{2 \omega}=0.532 \mu \mathrm{m}\right)$, measurement of the $I_{2} \omega$ second optical harmonic signal. Two $A_{n} B_{n-1} \mathrm{O}_{3 n}$ compounds with SPS have been used as the etalons, namely: $\mathrm{Sr}_{6} \mathrm{Nb}_{4} \mathrm{TiO}_{18}$ with $R 3 m$ noncentrosymmetric space group [13] and $\mathrm{Ba}_{2} \mathrm{La}_{4} \mathrm{Ti}_{5} \mathrm{O}_{18}$ with $R-3$ centrosymmetric space group [17].

\section{References}

[1]. M.T. Sebastian, Dielectric Materials for Wireless Communication, Elsevier, Oxford, 2008.

[2]. F. Lichtenberg, A. Herrnberge, K. Weidenmann, Prog Solid State Chem. 2008, 36, 253-387.

[3]. L. Fang, H. Zhang, T.H. Huang, R.Z. Yuan, R. Dronskowski, Mater. Res. Bull. 2004, 39, 1649 1654.

[4]. R. Rawai, A.J. McQueen, L.J. Gillie, N.C. Hyatt, E.E. McCabe, K. Samara, N. McN. Alford, A. Feteira, I.M. Reaney, D.C. Sinclair, Appl. Phys. Lett. 2009, 94, 192904-1-192904-3.

[5]. X. Kuang, M.M.B. Allix, J.B. Claridge, H.J. Niu, M.J. Rosseinsky, R.M. Ibberson, D.M. Iddles, J. Mater. Chem. 2006, 16, 1038-1045.
[6]. L. Fang, H. Zhang, L. Chen, R.Z. Yuan, R. Dronskowski, J. Mater. Sci. Mater. Electron. 2005, 16, 43-46.

[7]. L. Fang, H. Zhang, R.Z. Yuan, R. Dronskowski, J. Mater. Sci. 2004, 39, 7093-7095.

[8]. H. Zhang, L. Fang, R. Dronskowski, P. Muller, R.Z. Yuan, J. Solid State Chem. 2004, 177, 4007-4012.

[9]. L. Fang, L. Chen, H. Zhang, X.K. Hong, C.L. Diao, H.X. Liu, J. Mater. Sci. Mater. Electron. 2005, 16, 149-151.

[10]. H. Oshato J. Ceram. Soc. Jap. 2005, 113, 703711.

[11]. N.I. Santha and M.T. Sebastian, J. Am. Ceram. Soc. 2007, 90, 496-501.

[12]. S.K. Singh, V.R.K. Murthy, Mater. Chem. Phys. 2015, 160, 187-193.

[13]. A.R. Drews, W. Wong-Ng, T.A Vanderah, R.S Roth, J. Alloys Compd. 1997, 255, 243-247.

[14]. V.V. Polubinskii, Y.A Titov, N.M Belyavina, V.Ya. Markiv, M.S. Slobodyanik, V.V. Chumak, O.I. Nakonechna, Solid State Sci. 2014, 29, 1-5.

[15]. V. Markiv and N. Belyavina, Proc. of the Second Inter. Sci. Conf. of Engineering and Functional Materials, EFM-97, Lviv, 1997, 260-261.

[16]. A.P Leonov and S.Yu Stefanovich. In: Producing and Application of Ferroelectrics in National Economy, Moscow, 1984, 21-36, (in Russian).

[17]. N. Teneze, D. Mercurio, G. Trolliard, D. Fruit, Mater. Res. Bull. 2000, 35, 1603-1614.

[18]. H.C Duivenboden, H.W Zandbergen, D.J.W. Ijdo, Acta Crystallogr. 1986, C 42, 266-268.

[19]. R.D Shannon, Acta Crystallogr.1976, A 32, 751767.

[20]. I.D Brown and D. Altermatt, Acta Cryst. 1985, B 41, 244-247. 